JIPSI: Jurnal Ilmiah Ilmu Pengetahuan Sosial Indonesia

Nomor 1 Volume 1 Tahun 2021, hal 91-105

\title{
MODEL PENILAIAN PORTOFOLIO SEBAGAI UPAYA MENINGKATKAN HASIL BELAJAR IPS TERPADU
}

\author{
${ }^{1}$ Muhammad Yogi Andrian Syah, ${ }^{2}$ Risma Dwi Arisona \\ ${ }^{1}$ Institut Agama Islam Negeri Ponorogo \\ Muhammadyogiandrian97@gmail.com \\ ${ }^{2}$ Institut Agama Islam Negeri Ponorogo \\ arisona@iainponorogo.ac.id
}

\begin{abstract}
ABSTRAK
Penelitian ini mengkaji Model Penilaian Portofolio yang dilakukan di kelas VII MTs AnNajiyah. Penelitian ini bermaksud untuk mengetahui model penilaian portofolio mapel IPS Terpadu di kelas VII MTs An-Najiyah dengan fokus guru pada perencanaan model penilaian portofolio, pelaksanaan model penilaian portofolio, serta hasilnya. Juga dapat diartikan sebagai informasi sejauh mana guru IPS Terpadu dalam melaksanakan tugas sebagai guru, didalam melaksanakan tugas serta melakukan kewajibannya sebagai mendidik dan pendidik salah satunya pada proses penilaian portofolio yang begitu penting untuk guru, murid, madrasah, dan orang tua. Metode yang digunakan adalah metode penelitian kualitatif, penelitian lapangan yang merupakan studi kasus. Data yang dikumpulkan dengan cara metode wawancara, observasi, serta dokumentasi. Penganalisisan data yang dilakukan adalah analisis kualitatif, antara lain, reduksi data, sajian data, dan penarikan kesimpulan. Penelitian ini menghasilkan informasi bahwa (1) Perencanaan penialian portofolio yaitu dengan meyiapkan komponen penilaian dan penugasan berbentuk pertanyaan lisan, pilihan ganda, uraian, dan tugas proyek peta konsep, sebelum kegiatan penilaian berlangsung, guru memberikan tugas dengan spontan maupun melihat kondisi kesiapan dari siswa. (2) Pelaksanaan penilaian portofolio dilakukan oleh guru IPS dengan memperhatikan aspek proses pengerjaan tugas dan juga hasilnya, dengan begitu guru akan bisa mengontrol perilaku siswa serta hasil belajar siswa. (3) Hasil penilaian portofolio dibagi menjadi dua jenis, yaitu: penilaian portofolio proses dan penilaian portofolio produk. Dengan menggunakan metode penilaian portofolio dapat meningkatkan hasil belajar IPS Terpadu dikelas VII MTs AnNajiyah.

Kata Kunci : Portofolio, Hasil Belajar IPS Terpadu
\end{abstract}

\section{ABSTRACT}

This study examines the Portfolio Assessment Model conducted in class VII MTs An-Najiyah. This study intends to determine the Integrated Social Studies portfolio assessment model in class VII MTs An-Najiyah with the teacher's focus on planning a portfolio assessment model, implementing a portfolio assessment model, and the results. It can also be interpreted as information on the extent to which Integrated Social Studies teachers carry out their duties as teachers, in carrying out their duties and carrying out their obligations as educating and educators, one of which is the portfolio assessment process which is very important for teachers, students, madrasas, and parents. The method used is a qualitative research method, field research which is a case study. Data collected by means of interviews, observation, and documentation. The data analysis carried out is qualitative analysis, among others, data reduction, data presentation, and drawing conclusions. This study resulted in information 
that (1) Planning for portfolio assessment is by preparing assessment components and assignments in the form of oral questions, multiple choice, descriptions, and concept map project assignments, before the assessment activity takes place, the teacher gives assignments spontaneously and sees the readiness condition of students. (2) The implementation of portfolio assessment is carried out by social studies teachers by paying attention to aspects of the task process and also the results, so the teacher will be able to control student behavior and student learning outcomes. (3) The results of the portfolio assessment are divided into two types, namely: process portfolio assessment and product portfolio assessment. By using the portfolio assessment method can improve the learning outcomes of Integrated Social Studies in class VII MTs An-Najiyah.

Keywords: Portfolio, Integrated Social Studies Learning Outcomes

\section{A. PENDAhUluan}

Evaluasi hasil belajar dalam UU Sisdiknas No. 20 Tahun 2003 Pasal 57 menyebutkan bahwa evaluasi dilakukan dalam rangka pengendalian mutu pendidikan secara Nasional sebagai bentuk akuntabilitas penyelenggara pendidikan kepada pihak-pihak yang berkepentingan, dan pasal 58 menyebutkan bahwa evaluasi hasil belajar peserta didik dilakukan oleh pihak pendidik untuk memantau proses, kemajuan dan perbaikan hasil belajar peserta didik secara berkesinambungan. ${ }^{1}$

Pentingnya pemilihan jenis penilaian yang tepat tercantum pada Peraturan Presiden Nomor 2 Tahun 2015 tentang Rencana Pembangunan Jangka Menengah Nasional 2015-2019 menjelaskan bahwa sasaran pembangunan dibidang pendidikan antara lain peningkatan kualitas pelayanan pendidikan, tersedianya kurikulum yang handal dan tersedianya sistem penilaian yang komprehensif. Serta dalam Peraturan Pemerintah R.I. No.19/2005 tentang Standar Nasional Pendidikan Ayat: (11) tentang standar nasional pendidikan yang berkaitan dengan mekanisme, prosedur, dan instrumen penilaian hasil peserta didik, didukung dengan Ayat (17 yang berbunyi penilaian dilakukan dengan cara pengumpulan dan pengolahan informasi untuk mengukur pencapaian hasil belajar. Ditegaskan kembali pada Bab IV Pasal 22 Ayat (2) tentang teknik penilaian dapat berupa tes tertulis, observasi, tes praktik dan penguasaan perseorangan atau kelompok. ${ }^{2}$

Penilaian adalah salah satu upaya atau tindakan untuk mengetahui sejauh mana pencapaian atau tujuan yang telah ditetapkan. Salah satunya teknik penilaiannya dengan

\footnotetext{
${ }^{1}$ Rusdiana, Konsep Inovasi Pendidikan, ( Bandung: CV Pustaka Setia, 2014), 207.

${ }^{2}$ Zinal Arifin, evaluasi pembelajara, (Bandung: Remaja Rosdakarya,2011), hlm. 45.
} 
model penilain portofolio. Dalam dunia pendidikan,portofolio dapat digunakan guru untuk melihat perkembangan peserta didik dari waktu ke waktu berdasarkan kumpulan hasil karya sebagai bukti dari suatu kegiatan pembelajaran. Portofolio juga dapat dipandang sebagai collection of learning exsperience yang terdapat di dalama pikiran peserta didik, baik yang berwujud pengetahuan (cognitive), keterampilan (pyschomotor) maupun sikap dan nilai (affective). ${ }^{3}$

Menurut Yosi, Nurhayati, Rika, Didi dan Afrina Serta Sumardi mengatakan bahawa Penilaian portofolio merupakan bentuk nontes, representasi kerja siswa dan sekumpulan karya peserta didik yang tersusun secara sistematis dan terorganisasi yang diambil selama proses pembelajaran yang dikumpulkan selama kurun waktu tertentu, dan fokus dalam pemecahan masalah, berpikir dan pemahaman, komunikasi tertulis, yang digunakan guru dan peserta didik untuk memantau perkembangan pengetahuan peserta didik, keterampilan peserta didik, dan sikap peserta didik dalam mata pelajaran tertentu serta untuk melihat ketercapaian kompetensi belajar peserta didik.

Hal- hal yang dapat dijadikan bahan penilaian portofolio di sekolah antara lain: penghargaan tertulis, penghargaan lisan, hasil pelaksanaan tugas-tugas siswa, daftar ringkasan hasil pekerjaan, catatan sebagai peserta dalam suatu kerja kelompok. Selain dapat digunakan untuk memantau perkembangan siswa dan mendiagnosis kesulitan belajar mereka, penilaian portofolio juga sangat bermanfaat bagi guru untuk menilai kebutuhan (need),minat (interest), kemampuan akademik (abilities). Dan karakteristik siswa secara perseorangan. Portofolio digunakan untuk memperbaiki kelemahan serta kekurangannya dalam proses pembelajaran maupun penguasaannya tentang suatu pokok bahasan atau materi pemebelajaran tertentu. ${ }^{4}$

Berdasarkan uraian di atas peneliti mencoba mengadakan penelitian tentang bagaimana model penilaian portofolio sebagai upaya meningkatkan hasil belajar IPS terpadu di MTs An-Najiyah, dengan cara melakukan penelitian tentang bagaimana perencanaan, pelaksanaan dan hasil model penilaian portofolio yang digunakan untuk meningkatkan hasil belajar IPS Terpadu.

\footnotetext{
${ }^{3}$ Zinal Arifin, evaluasi pembelajara, (Bandung: Remaja Rosdakarya,2011), 197.

${ }^{4}$ Ida Farida, evaluasi pembelajaran, (Bandung: Remaja Rosdakarya,2017), hlm. 120.
} 


\section{B. KAJIAN PUSTAKA}

Penilaian portofolio merupakan penilaian melalui koleksi karya (hasil kerja) siswa yang sistematis, yakni meliputi: pengumpulan data melalui karya siswa, pengumpulan dan penilaian yang terus menerus, refleksi perkembangan berbagai kompetensi, memeperlihatkan tingkat perkembangan kemajuan belajar siswa, bagian integral dari proses pembelajaran, untuk satu periode, dan tujuan diagnostik.

Agar koleksi hasil kerja siswa dapat disebut portofolio, diperlukan persyaratan sebagai berikut:Sebuah portofolio seharusnya mengandung kerja original siswa dalam periode tertentu.Koleksi hasil kerja dalam portofolio seharusnya memperlihatkan aspek-aspek yang berbeda dari kemampuan siswa. Koleksi tersebut menunjukkan bukti-bukti kemampuan dan kompetensi siswa didalam satu bidang atau lebih. ${ }^{5}$

Jenis penilaian portofolio akan memeberikan pemahaman tentang perlunya penggunaan penilaian portofolio secara bervariasi sesuai dengan jenis kegiatan belajar peserta didik. ${ }^{6}$ Tapi pada hakikatnya penilaian portofolio dibedakan menjadi dua yaitu:Pertama, Penilaian portofolio proses, penilaian tersebut berorientasi proses merupakan pada tahapan belajar sehingga menyajikan catatan perkembangan siswa dari waktu ke waktu. Salah satu bentuk portofolio proses adalah portofolio kerja (working portofolio) yaitu bentuk yang digunakan untuk memantau kemajuan dan menilai peserta didik dalam mengelola kegiatan belajar mereka sendiri. Peserta didik mengumpulkan semua hasil kerja termasuk coretancoretan (sketsa), buram, catatan, kumpulan untuk rangsangan, buram setengah jadi, dan pekerjaan yang sudah selesai. Portofolio kerja bermanfaat untuk memeberikan informasi bagaimana siswa: mengorganisasikan dan mengelola kerja, merefleksi dari pencapaiannya, dan menetapkan tujuan dan arahan. ${ }^{7}$ Kedua, Penilaian portofolio produk, penilaian tersebut menekankan pada tinjauan hasil terbaik yang telah dilakukan diswa, tanpa memperhatikan bagaimana proses untuk mencapai kinerja itu terjadi. Jadi bentuk penilaian portofolio produk hanya

\footnotetext{
${ }^{5}$ Ida Farida, evaluasi pembelajaran, (Bandung: Remaja Rosdakarya,2017), hlm. 118.

${ }^{6}$ Zainal Arifin, evaluasi pembelajaran, (Bandung: Remaja Rosdakarya,2011), hlm.206.

${ }^{7}$ Ida Farida, evaluasi pembelajaran, (Bandung: Remaja Rosdakarya,2017), hlm. 122.
} 
menekankan pada penguasaan (mastery) dari tugas yang dituntut dalam standart kompetensi, kompetensi dasar, dan sekumpulan indikator pencapaian hasil belajar, serta hanya menunjukkan kinerja yang paling baik, tanpa memperhatikan bagaimana dan kapan kinerja itu diperoleh. Contoh portofolio produk adalah portofolio tampilan (show portofolio), dan portofolio dokumentasi (documentary portofolio $)^{8}$

Hasil belajar dapat diperoleh dari proses penilaian. Penilaian dilakukan dengan memperhatikan kriteria-kriteria hasil belajar yang dapat dicapai oleh siswa. Hasil belajar yang dilakukan siswa dapat maksimal apabila pembelajran dilakukan secara menyenangkan.Nana Sudjana dalam bukunya mengatakan bahwa hasil belajar adalah suatu pengalaman belajar yang dimiliki siswa dilihat dari kemampuan-kemampuan siswa tersebut. ${ }^{9}$ Menurut Bloom, hasil belajar dapat dikelompokkan dalam tiga doamain, yaitu kognitif, afektif, dan psikomotor. Setiap domain disusun menjadi beberapa jenjang kemampuan, mulai dari hal yang sederhana hingga hal yang kompleks, mulai dari hal yang mudah hingga dengan hal yang sukar, dan mulai dari hal yang konkret hingga dengan hal yang abstrak. $^{10}$

\section{METODE PENELITIAN}

Metodologi yang digunakan dalam penelitian ini menggunakan pendekatan kualitatif, mempunyai definisi cara ilmiah guna memperpleh data yang valid (soheh) memiliki tujuan dapat ditemukan, dibuktikan serta dikembangkan suatu pengetahuan sehingga bisa dipakai untuk memahami, memecahkan dan mengantisipasi permasalahan didalam data serta memiliki tingkat akurasi yang mendalam. ${ }^{11}$

Denzin dan Lincoln menyatakan bahwa penelitian kualitatif adalah penelitian yang menggunakan latar belakang alamiah, dengan maksud

\footnotetext{
${ }^{8}$ Ibid. 124.

${ }^{9}$ Nana Sudjana, Penilaian Hasil Proses Belajar Mengajar, (Bandung: PT Remaja Rosdakarya, 2014), 22. 2015), 63 .

${ }^{10}$ Elis Ratnawulan dan Rusdiana, Evaluasi Pembelajaran, (Bandung: CV Pustaka Setia,

${ }^{11}$ Abdul Manab, Penelitian PendidikanPendekatan Kualitatif(Yogyakarta: Kalimedia, 2015), 1.
} 
menafsirkan fenomena yang terjadi dan dilakukan dengan jalan melibatkan metode yang ada dalam penelitian kualitatif. Metode yang biasanya dimanfaatkan adalah wawancara, pengamatan, dan pemanfaatan dokumen. ${ }^{12}$. Teknik pengumpulan data yang dimaksud adalah observasi, wawancara, dan dokumentasi. Bagi peneliti kualitatif menemukan fenomena melaui observasi, malalui wawancara yang mendalam untuk mendapat data yang dibutuhkan untuk penelitian, dan didukung lewat dokumentasi.

Tahapan ini diawali dari mendapat kasus yang memiliki keunikan, yang mana prosesnya secara induktif, teori yang dipakai menjadi perangkat guna memandu peneliti memahami fenomena, lebih memfokuskan ke dalam daripada luasnya kajian, yang diakhiri dengan teori baru. Memiliki ntujuan untuk mendapat pemahaman yang lebih mendalam mengenai perilaku, proses interaksi, makna suatu tindakan, nilai, pengalaman perseorangan maupun kelompok, yang keseluruhannya berlangsung dalam latar alami. ${ }^{13}$

Penelitian ini berjenis field reasearch, maksudnya adalah penelitian yang dilaksanakan langsung dilapangan guna mendapatkan data yang dibutuhkan. Dalam penelitian ini desain yang digunakan adalah desain penelitian studi kasus, yang mana penelitian mengfokuskan pada fenomena yang kemudian dipahami dan dianalisa secara mendalam. ${ }^{14}$

\section{HASIL DAN PEMBAHASAN}

\section{Tahap Perencanaan}

Pembahasan dalam penelitian ini berisi tentang hasil penelitian model penilaian portofolio dengan metode penelitiannya kualitatif yang dilakukan peneliti yang bekerjasama dengan guru IPS Terpadu kelas VII MTs An-Najiyah. Beberapa hal yang dijelaskan dalam pembahasan adalah suatu yang berkaitan tentang perencanaan model penilaian portofolio, pelaksanaan model penilaian

\footnotetext{
${ }^{12}$ Umar Sidiq, dan Moh. Miftachul Choiri, Metode Penelitian Kualitatif di Bidang Pendidikan (Ponorogo: CV Nata Karya, 2019), 4.

${ }^{13}$ Abdul Manab, Penelitian PendidikanPendekatan Kualitatif(Yogyakarta: Kalimedia, 2015), 4.

${ }^{14}$ Nana Saodih Sukmadinata, Metode Penelitian Pendidikan. (Bandung: PT Remaja Rosdakarya, 2005), 99.
} 
portofolio, dan hasil model penilaian portofolio, yang dialakukan sebagai upaya untuk meningkatkan hasil belajar IPS terpadu.

Diawali dengan perencanaan model penilaian portofolio, Berkegiatan atau melakukan sebuah tindakan kependidikan selalu dimulai dengan perencanaan atau disebut juga dengan persiapan. Seorang guru sebelum memulainya, guru memberikan pelajaran awal tahun, pertanyaan yang muncul adalah apakah yang akan dicapai oleh siswa melalui pelajaran saya ini, dan untuk mengarahkan ke pencapaian tujuan, apakah siswa sudah mempunyai bekal berupa kemampuan ataupun sebagian dari yang akan dicapai sehingga guru tidak perlu memberikan bahan seluruhnya. ${ }^{15}$

Kegiatan ini adalah menilai, menilai memiliki maksud mengambil suatu keputusan terhadap sesuatu dengan ukuran baik buruk,penilaian bersifat kualitatif. Secara rinci dan sesuai dengan urutan kejadiannya, dalam proses transformasi ini penialaian dibedakan atas tiga jenis, yakni sebelum, selama, dan sesudah terjadi proses dalam kegiatan sekolah. Dalam hal ini para pelaksana pendidikan slalu berorientasi pada tujuan yang akan dicapai dan tujuannya selalu diarahkan pada siswa secara perseorangan (individual) maupun secara kelompik (perkelas). Sehubungan dengan dengan perincian ini, yang bisa dilakukan oleh pendidik adalah mengajukan pertanyaan-pertanyaan sebagai satu ungkapan penilaian yang akan dicari jawabnya. ${ }^{16}$

Prakteknya kegiatan perencanaan dilakukan oleh guru IPS Terpadu di kelas VII MTs An-Najiyah karena sadar pentingnya proses perencanaan bagi setiap kegiatan termasuk penilaian portofolio. Pembuatan perencanaan oleh guru dimulai dari penugasan-penugasan, pertanyaan lisan, pilihan ganda, maupun uraian. Dengan melakukan perencanaan dengan matang maka pelaksanaannya juga akan maksimal serta sesuai dengan kompetensi yang dituju. Adanya pernyataan tersebut maka guru melakukan penilaian portofolio lewat penugasanpenugasan, penugasan-penugasan tersebut berebentuk tes pertanyaan lisan, pilihan ganda. Uraian dan tugas proyek membuat peta konsep yang dijadikan

\footnotetext{
${ }^{15}$ Suharsimi Arikunto, Dasar Dasar Evaluasi Pendidikan, (Jakarta: PT Bumi Aksara: 2003), 8.
}

${ }^{16}$ Ibid., 16. 
sebagai penilaian portofolio. Bahan yang digunakan untuk penilan portofolio ini berasal LKS dan lembar kerja hasil karya murni dari siswa.

Penggunaan tes pertanyaan lisan bertujuan untuk mengetahui kecakapan dalam menjawab serta mengetahui pemahaman siswa tentang materi yang disampaikan, hampir sama dengan soal uraian namun bedanya pada jika soal uraian ditulis sedangkan tes lisan secara ucapan. Dalam kagiatan ini guru IPS Terpadu melontarkan pertanyaan kepada siswa dan siswa tersebut menjawab secara baik dan benar. Sedangkan untuk pilihan ganda atau multiple choice test terdiri atas suatu keterangan atau pemberitahuan tentang suatu pengertian yang belum lengkap. Dalam kegiatan ini murid melengkapinya harus memilih salah satu dari beberapa kemungkinan jawaban yang telah disediakan. dalam tes pilihan ganda ini guru memberikan atau menunjukkan pertanyaan dalam LKS dan siswa menjawab pertanyaan tersebut dengan memilih kemungkinan jawaban yang telah tersedia. Kemungkinan jawaban benar itu terdiri dari jawaban jawaban yang salah dan satu jawaban benar.

Tes uraian yaitu menyampurnakan atau melengkapi, terdiri atas kalimat kalimat yang ada bagian-bagian yang dihilangkan. Bagian yang dihilangkan atau yang harus di isi oleh murid adalah merupakan pengertian yang kita minta dari murid. Dalm tes uraian ini guru membarikan soal tulis dan siswa menjawab tanpa ada pilihan jawaban jadi jawabnnya murni dari pemikiran dan pemahaman siswa.

Sesuai pedoman model penilaian yang dikeluarkan oleh pusat kurikulum Balitbang Diknas yang dimaksud penilaian proyek adalah sebuah kegiatan penilaian terhadsp suatu tugas yang harus diselesaikan dalam periode waktu tertentu. Tugas proyek tersebut seperti halnya tugas menghasilkan produk, yaitu dimulai dari tahap perencanaan.${ }^{17}$. dalam hal ini guru IPS Terpadu menerapkan tugas proyek dengan membuat peta konsep. Guru IPS memberikan tugas membuat peta konsep materi Aktivitas Manusia dalam Memenuhi Kebutuhan lalu siswa mengerjakan tugas tersebut dalam lembar kerja

Penugasan penugasan diatas guru IPS Terpadu mengkalsifikan dan mengakumulasi ke dalam portofolio proses dan produk. Portofolio lebih

${ }^{17}$ Ibid, .251. 
cenderung pada penilaian perilaku siswa ketika dan setelah mengerjakan tugas tersebut, sedangkan untuk portofolio produk diambil dari akumulasi tugas pertanyaan lisan, pilihan ganda, pertanyaan uraian atau isian dan penilaian terhadap proyek yang telah dikerjakan.

\section{Tahap Pelaksanaan}

Penilaian portofolio pada pelajaran IPS Terpadu termasuk tanggungjawab guru sebagai evaluator, menjadikan guru tidak hanya melaksanakan perencanaan atas penilaian portofolio saja namun juga melaksanakannya. Di kelas VII tidak hanya melakukan satu bentuk tes, namun menggunakan beberapa bentuk tes. Dalam pelaksanaan penilaian portofolio guru mengetahui standart pelaksanaan penilaian yaitu: pendidik melakukan kegiatan penilaian sesuai rencana penilaian yang telah disusun di awal pembelajaran, pendidik menganalisis kualitas instrumen dengan mengacu pada persyaratan instrumen serta menggunakan acuan kriteria, pendidik menjamin pelaksanaan ulangan atau penugasan yang bebas dari kemungkinan terjadinya kecurangan, dan pendidik memeriksa pekerjaan peserta didik dan memberikan umpan balik dan komentar yang bersifat mendidik. ${ }^{18}$

Guru memberikan berbagai bentuk tes untuk menilai, tes yang diberikan guru IPS Terpadu adalah tes lisan dan tulis. Dalam pelaksanaan tes lisan guru harus memperhatikan tempat diadakan tes. Guru harus dapat menciptakan suasana yang kondusif dan komunikatif, tetapi bukan berarti menciptakan suasana tes lisan menjadi diskusi, debat atau ngobrol santai. Komunikatif dimaksudkan agar guru dapat mengarahkan peserta didik, terutama bila jawaban peserta didik tidak sesuai dengan apa yang guru maksudkan. Mengarahkan berbeda dengan membantu, mengarahkan berarti memberi pengarahan secara umum untuk mencapai tujuan, sedangkan membantu berarti ada kecenderungan untuk memberi bunyi jawaban kepada peserta didik. Ada baiknya, sebelum tes lisan dimulai, guru menyiapkan pokok-pokok materi yang akan ditanyakan, sehingga tidak terkecoh oleh jawaban peserta didik yang masih simpang siur. Pemberian tes lisan kepada siswa ketika guru ingin mengetahui sejauh mana pemahaman tenatang materi.

${ }^{18}$ Zinal Arifin, evaluasi pembelajaran, (Bandung: Remaja Rosdakarya,2011), 55. 
Dasarnya pelaksanaan penilaian portofolio adalah memberikan tes kepada peserta didik, dan kemudian hasil tes-tes tersebut karya atau hasil siswa belajar siswa berupa hasil tes-tes, tugas individu maupun proyek yang merupakan murni hasil karya siswa sendiri yang berwijud benda, dan yang dinilaia adalah prosese kemajuannya, baik secara analitik, holistik atau kombinasi keduanya. ${ }^{19}$ Dengan adanya kegiatan tersebut murid menjadi terbiasa dalam memecahkan persoalan ataupun menganalisa sebuah permasalahan dan itu bertujuan untuk meningkatkan hasil belajar siswa tidak hanya pada materi Aktivitas Manusia dalam Memenuhi kebutuhan tapi juga pelajaran IPS Terpadu khususnya dan bermanfaat bagi pemikiran mata pelajaran lain karena pemahaman siswa sering diasah, dan terbiasa dalam menjawab persoalan serta tidak terjadi keragu-araguan dalam menjawab setiap persoalan atau permasalahan.

Guru memberikan berbagai bentuk tes untuk menilai, tes yang diberikan guru IPS Terpadu adalah tes lisan dan tulis. Dalam pelaksanaan tes lisan guru harus memperhatikan tempat diadakan tes. Guru harus dapat menciptakan suasana yang kondusif dan komunikatif, tetapi bukan berarti menciptakan suasana tes lisan menjadi diskusi, debat atau ngobrol santai. Komunikatif dimaksudkan agar guru dapat mengarahkan peserta didik, terutama bila jawaban peserta didik tidak sesuai dengan apa yang guru maksudkan. Mengarahkan berbeda dengan membantu, mengarahkan berarti memberi pengarahan secara umum untuk mencapai tujuan, sedangkan membantu berarti ada kecenderungan untuk memberi bunyi jawaban kepada peserta didik. Ada baiknya, sebelum tes lisan dimulai, guru menyiapkan pokok-pokok materi yang akan ditanyakan, sehingga tidak terkecoh oleh jawaban peserta didik yang masih simpang siur. Pemberian tes lisan kepada siswa ketika guru ingin mengetahui sejauh mana pemahaman tenatang materi.

Sedangkan teknik tes tulis meliputi menjawab pilihan ganda, uraian dan proyek, pemberian tes tulis kepada siswa yang penyajiannya berbentuk tulisan yang dijawab siswa, tes tulis tersebut berisi antara lain pilihan ganda dan uaraian dengan tetap memperhatikan soal pengalokasian waktu yang disediakan.

\footnotetext{
${ }^{19}$ Suharsimi Arikunto, Dasar Dasar Evaluasi Pendidikan, (Jakarta: PT Bumi Aksara: 2003),
} 212. 
Melakukan kegiatan penilaian maka guru harus melakukan secara terus menerus. Sehingga kegiatan penilaian dapat dikatakan valid. Data yang didapatkan benar-benar dapat mewakili hsil belajar siswa. ${ }^{20}$ Maka dari itu guru mengadakan penilaian di setiap pertemuan minimal melaksanakan tes lisan. Sedangkan untuk beberapa pertemuan guru memberikan tugas siswa berupa tugas proyek, dengan begitu guru dapat mengkontrol perkembangan siswa disetiap materi, yang akhirnya tujuan adanya penilaian portofolio akan dapat dipenuhi. Prinsipnya penilaian portofolio harus dilaksanakan terus menerus dalam jangja waktu tertentu. Pada saat data terkumpul, guru juga harus secara terus menerus mengadakan analisis terhadap siswa ataupun model penilaian yang diterapkan.

Selain memberikan tes tulis dan lisan, guru IPS Terpadu kelas VII juga melaksanakan penialaian proses. Sikap dan perilaku siswa juga tak luput dari pengawasan guru. Guru mengamati sikap dan perilakau siswa pada saat proses pembelajaran berlangsung atau pada saat dan setelah pemberian tugas tes. Hal ini guru mempunyai pedoman penilaian yaitu skala sikap,. Akan tetapi skala sikap ini tidak diterapkan dalam setiap pertemuan. Jadi ketika guru menngetahui siswa yang mempunyai sikap, tutur kata dan perilaku yang kurang baik, guru akan memberi teguran.

\section{Hasil}

Hasil penilaian portofolio ini berbentuk dua jenis yaitu berjenis portofolio proses dan portofolio produk. Guru IPS Terpadu kelas VII menggunakan portofolio proses untuk menolong siswa mengidentifikasi tujuan pembelajaran, perkembangan hasil belajar dari waktu ke waktu, dan menunjukkan pencapaian hasil belajar. Pendekatan ini lebih menekankan pada bagaimana siswa belajar, berkreasi. Salah satu bentuk portofolio proses adalah portofolio kerja yaitu bentuk yang digunakan untuk memantau kemajuan dan menilai peserta didik dalam mengelola kegiatan belajar mereka sendiri. Peserta didik mengumpulkan semua hasil kerja termasuk coretan-coretan sketsa dan pekerjaan yang sudah selesai. Portofolio kerja bermanfaat untuk meberikan informasi bagaimana siswa:

${ }^{20}$ Zainal Arifin, Evaluasi pembelajaran teori teknik penerapan, 37. 
mengorganisasikan dan mengelola kerja, merefleksi dari pencapaiannya, dan menetapkan tujuan dan arahan.

Untuk hasil ini dapat menginformasikan dari diskusi antara siswa dan guru. Melalui portofolio proses ini, guru dapat membantu siswa mengidentifikasi kekuatan dan kelemahan masing masing. Informasi ini dapat digunakan untuk memperbaiki cara belajar siswa.keberhasilan portofolio proses ini bergantung pada kemampuan untuk merefleksikan dan mendokumentasikan kemajuan proses pembelajaran. Karena dalam paradigma lama, penilaian pembelajaran lebih ditekankan pada hasil produk dan cenderung hanya menilai kemampuan aspek kognitif saja. ${ }^{21}$

Kemudian untuk hasil portofolio produk adalah penilaian portofolio produk, portofolio produk di kelas VII MTs An-Najiyah diambil dari akumulasi penugasan penugasan yang telah diberikan oleh guru dan dikerjakan oleh siswa. Termasuk juga peta konsep sebagi tugas proyek. Produk akhir sebuah proyek memerlukan penilaian khusus. Penilaian produk dari sebuah proeyek bertujuan untuk menilai kualitas dan bentuk hasil akhir secara holistik dan analitis. Penilaian produk yang dihasilkan siswa meliputi kemampuan peserta didik menghasilkan produk seprti hasil karya seni gambaran, tulisan dan lain-lain. ${ }^{22}$

Semua hasil penilaian tersebut harus dilaorkan kepada pihak yang berkepentingan, seperti orang tua, kepala sekolah, atau peserta didik itu sendiri. Dalam hal ini bertujuan agar kegiatan pembelajaran yang didalamnya termasuk proses dan hasil belajar yang dicapai oleh siswa dpat diketahui oleh semua pihak, menjadikan pihak yang mendapatkan laporan tersebut dapat memilih tindak lanjut yang akan dilakukan. ${ }^{23}$

Bentuk laporan kemajuan peserta didik tersebut bersifat kualitatif dan kuantitatif, tidak hanya menampilkan angka, namun juga menampilkan penjelasan yang bersifat komunikatif. Laporan disusun dengan jenis penilaian portofolio proses dan produk pelajaran IPS Terpadu pada materi Aktivitas

${ }^{21}$ Elis Ratnawulansari dan Rusdiana, Evaluasi Pembelajaran, ( Bandung: CV Pustaka Setia, 2015). 58

${ }^{22} \mathrm{Ibid}, .300$.

${ }^{23}$ Zainal Arifin, Evaluasi Pembelajaran Prinsip Teknik Prosedur, 110. 
Manusia dalam Memenuhi Kebutuhan. Penilaian ini dirasa penting karena dapat digunakan untuk diagnosis terhadap peserta didik serta untuk mengupayakan perkembangan pesrta didik supaya hasil belajarnya meningkat.

Kurikulum 2013 ditekankan bahwa penilaian sikap dan perilaku merpakan hal yang penting. Maka dari itu penilaian proses perlu dilakukan tidak hanya melakukan penilaian hasil kerjanya saja. Karena itu setiap keberhasilan merupakan berawal dari sebuah proses yang baik dan terarah. Maka dengan menggunakan model penilaian portofolio ini sebagai salah satu upaya pendidik atau guru untuk meningkatkan hasil belajar siswanya terutama pada pembelajaran Ilmu Pengetahuan Sosial Terpadu, yang model ini berhasil meningkatkan hasil belajar siswa serta mengontrol setiap perkembangan siswa dari segi ranah kognitif, afektif, dan psikomotor.

\section{E. KESIMPULAN DAN SARAN}

Berdasarkan hasil penelitian dan pembahasan tentang Model Penilaian Portofolio Sebagai Upaya Meningkatkan Hasil Belajar IPS Terpadu pada Materi Aktivitas Manusia dalam Memenuhi Kebutuhan di Kelas VII MTs An-Najiyah, maka dapat diambil kesimpulan sebagai berikut:

Perencanaan penilaian portofolio di kelas VII telah dirumuskan oleh guru IPS Terpadu sebelum kegiatan penilaian berlangsung dengan cara bisa spontan maupun melihat kondisi kesiapan dari siswa. Yaitu dengan membuat form atau lembar penilaian portofolio proses dan portofolio produk. Serta membuat instrumen tes dan penugasan yang berbentuk pertanyaan lisan, pilihan ganda, soal uraian, dan tugas proyek ( peta konsep), dan secara rinci mencantumkan sistematika penugasannya. Serta guru menentukan tujuannya dengan adanya penilaian portofolio tersebut, khususnya tugas peta konsep dengan memberi gambaran awalnya dan secara keseluruhan mencangkup kompetensi inti (K.I 3 K.I 4). Pelaksanaan Model Penilaian Portofolio kelas VII materi Aktivitas Manusia dalam Memenuhi Kebutuhan dilaksanakan guru IPS Terpadu dengan melaksanakan penugasan yang berasal dari LKS yang berbentuk pertanyaan lisan, pilihan ganda, soal uraian dan tugas proyek yang berupa membuat peta konsep. 
aspek yang di nilai adalah portofolio proses dan portofolio produk. Hasil evaluasi model penilaian portofolio materi aktivitas manusia dalam memenuhi kebutuhan hidup berupa data yang harus diolah guru. Guru IPS Terpadu melakukan penilaian dan analisis terhadap hasil penilaian portofolio proses dan portofolio produk tersebut. Apabila hasil produk tersebut kurang dari KKM yang telah ditentukan sebelumnya, maka guru melakukan remidi. Hasil seluruh penugasan di kelompokkan menjadi penilaian portofolio proses dan penialaian portofolio produk. Dengan menggunakan metode penilaian portofolio dapat meningkatkan hasil belajar IPS Terpadu dikelas VII MTs An-Najiyah dengan rata-rata nilai siswa adalah 75, sedangkan nilai KKM nya adalah 70 .

Mengenai sarannya adalah lembaga pendidikan dan khususnya guru-guru mata pelajaran, hendaknya melaksanakan penilaian dan melakukan persiapan dengan matang serta memperhatikan setiap perekembangan perilaku siswa, sehingga hasilnya bisa menjadi tolak ukur yang murni dari siswa dan untuk meningkatkan prestasi dan hasil belajar siswa secara maksimal.Hendaknya setiap guru memperhatikan setiap perilaku siswa pada saat jam pelajaran maupun diluar jam pelajaran, terutama dalam hal kedisiplinan waktu, dan berpakaian, sehingga mencipatakan suasana kelas yang kondusif.

\section{DAFTAR PUSTAKA}

Rusdiana. Konsep Inovasi Pendidikan. Bandung: CV Pustaka Setia, 2014.

Arifin, Zainal. Evaluasi Pembelajaran Prinsip, Teknik, Prosedur. Bandung: Remaja Rosdakarya,2011

Farida, Ida. Evaluasi Pembelajaran. Bandung: Remaja Rosdakarya, 2017.

Sudjana, Nana, Penilaian Hasil Belajar Mengajar, Bandung: PT Remaja Rosdakarya, 2014.

Ratnawulansari, Elis dan Rusdiana, Evaluasi Pembelajaran, Bandung: CV Pustaka Setia, 2015.

Manab, Abdul. Penelitian PendidikanPendekatan Kualitatif. Yogyakarta: Kalimedia, 2015. 
JIPSI: Jurnal Ilmiah Ilmu Pengetahuan Sosial Indonesia

Nomor 1 Volume 1 Tahun 2021, hal 91-105

Sidiq, Umar dan, Moh. Miftachul Choiri, Metode Penelitian Kualitatif di Bidang Pendidikan, Ponorogo: CV Nata Karya, 2019.

Sukmadinata, Nana Saodih, Metode Penelitian Pendidikan, Bandung: PT Remaja Rosdakarya, 2005.

Suharsimi Arikunto, Dasar Dasar Evaluasi Pendidikan, Jakarta: PT Bumi Aksara: 2003.

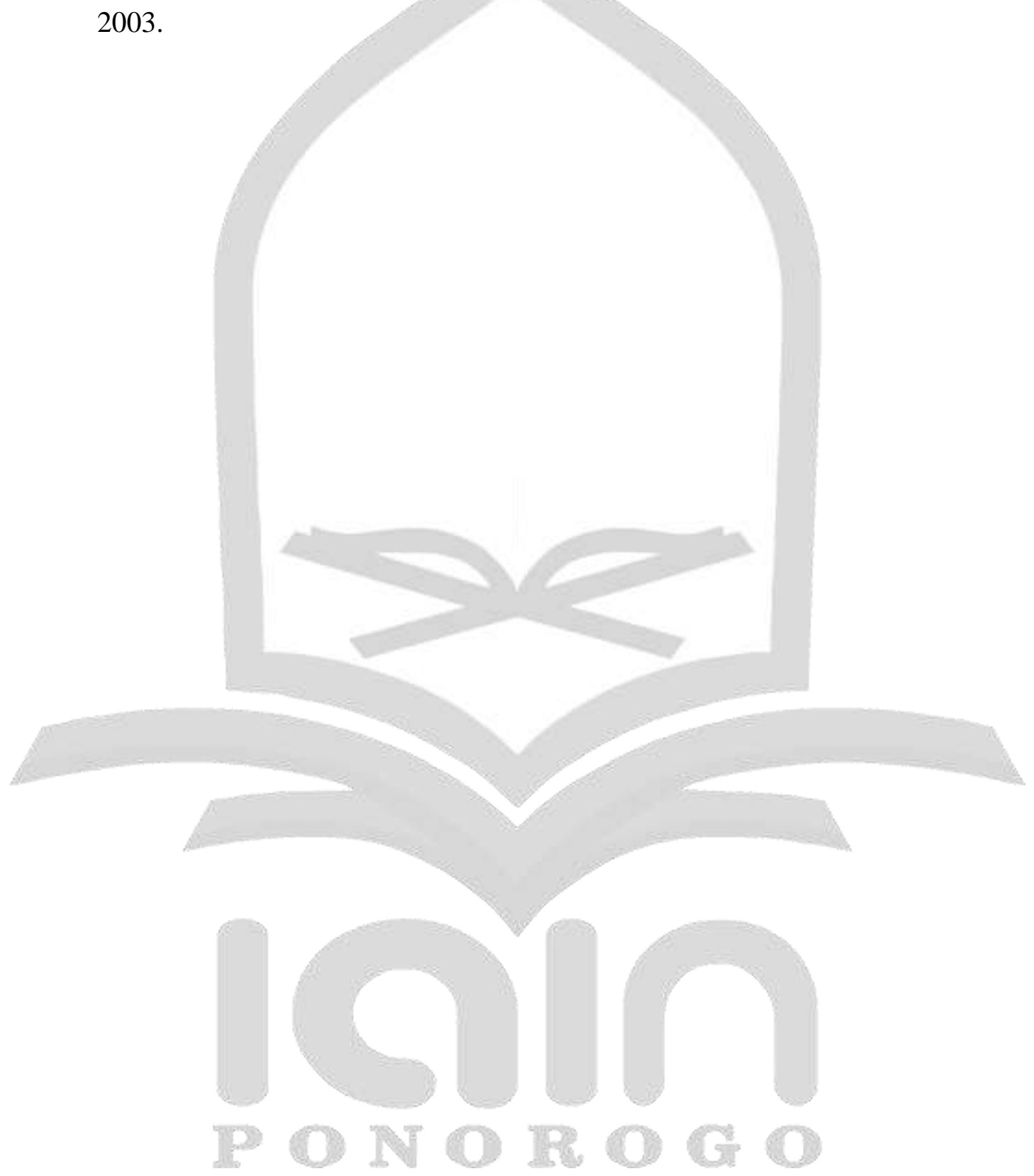

